\title{
Rethinking New Public Infrastructure Value for Money in Recession Times: The Greek Case
}

\begin{abstract}
The recent financial crisis in Europe has led to large reduction of public investment and urges the recession-hit countries to revisit their approach to new infrastructure projects initiation in light of the current budgetary constraints. This paper reviews the methodologies and practices implemented worldwide with the aim to achieve cost efficiency in infrastructure development and critically discuss the current approach to planning and designing of infrastructure projects in Greece. A number of transport infrastructure projects under tendering or construction, including urban express roads, urban development projects, cruise port, urban rail and airport, are presented and analyzed. The authors highlight the critical role of the implementation of appropriate tools and informed decision making in design and construction and present alternative solutions of enhanced cost efficiency for the required value for money to be achieved in each of the above projects.
\end{abstract}

\section{Keywords}

Cost efficiency, Greece, Infrastructure Design, Infrastructure Planning, Recession, Value for money.

\section{INTRODUCTION}


Large transportation infrastructures play a key role in promoting national and regional economies and competitiveness (Fabbro, Brunello and Dean 2015). For instance, the UK government's aim is that the currently planned infrastructure spending of $£ 310$ billion will promote growth, increase productivity and generate employment (National Audit Office 2013). Similarly, with the aim of adding stimulus and creating employment in a stagnant economy, the Irish government launched in 2012 a $€ 2.25$ billion investment plan for infrastructure procurement including roads, schools and other buildings (Reeves 2015).However, the recession across the world has led to ongoing transformations within the state and the market, brought active development projects to a grinding halt and forced countries and cities to question the very ways in which, sometimes for more than 50 years, the built environment has been managed (Bertolini et al. 2011). The urgency of the current crisis was evident by the growing threat of public-sector indebtedness and growing fears of sovereign defaults by highly indebted and less than transparent countries such as Greece, Italy, Portugal, Hungary and others (Lovering 2010).Particularly in Greece, the implementation of strict fiscal adjustment measures had significant recessionary effects on the economy which declined by over 23 per cent in 2007-2013 (Matsaganis and Leventi 2014); this made the role of effective targeting of public investment even more crucial than usually (Monastiriotis 2011).

Although any recovery plan has to be based on new investments in infrastructures (Dimitriou, Mourmouris and Sartzetaki 2015), in an era of tight public finances and government austerity, funds for public investment have been squeezed. Especially under the current deep recession of Greek economy, the first question for governments is where to find the money to make the necessary investments, traditionally paid for straight from the public purse in the past decades. 
Therefore, it is critical that decision makers establish value for money as the key criterion for infrastructure projects planning and resources allocation.

In this context, this paper reviews infrastructure appraisal practices widely used to safeguard the efficient use of scarce capital, including Value Management (VM), Value Engineering (VE) and Cost-Benefit Analysis (CBA) (Table 1). The authors also critically discuss the current approach to planning and design of infrastructure projects in Greece and identify good practices like design constructability and flexibility that Public Clients should implement during recession to improve the investment's value for money. Various infrastructure projects currently under design or tendering in Greece (urban express roads, urban development projects, cruise port, urban rail and airport) are used as examples and technical solutions of improved cost efficiency are provided.

\section{COST EFFICIENCY IN INFRASTRUCTURE PLANNING: EVIDENCE FROM THE LITERATURE AND THE PRACTICE}

The ability of any country to deliver infrastructure investment priorities efficiently and effectively is crucial to achieving growth objectives. In an era of austerity, governments and companies particularly seek to increase infrastructure's capital efficiency - that is the ratio of its output to the capital expenditure needed to operate it. The challenge is to maximize the value of assets and minimize the costs associated with building, operating and maintaining infrastructure (The Economist Intelligence Unit 2014). 
Value is a central concept in a project management context as it encompasses the project's lifecycle cost, as well as organizational, social and environmental aspects associated with its design, construction, operation and decommissioning of the project. According to Salvatierra-Garrido and Pasquire (2011) the main characteristics of the concept of value within the construction industry is that it is subjective, relative, context-dependent and dynamic. Its subjectivity emerges from the fact that value depends on the stakeholders' vision of the concept and its relativity is due to its comparative nature, closely related with the opportunity to use. Furthermore, value varies according to different contexts where it is measured or perceived, while its perception and interpretation changes across time. Defining value in the context of a specific project requires the structured approach of VM i.e. the process in which the functional benefits of a project are made explicit and appraised as consistent with a value system determined by the client. In this way, VM contributes to an explicit customer perspective of value from the early stage of projects, where opportunities to add values are increased (Kelly, Male and Graham 2004). Jay and Bowen (2013) provide a holistic and comprehensive historical perspective of the evolution of VM over the past 100 years, highlighting its substantial contribution to innovation. The attitudes and experiences of VM facilitators within major UK cost consultancies have been investigated by Ellis, Wood and Keel (2005).

The ultimate goal of the functional value analysis conducted in VM is the identification of the design alternative which achieves maximization of the design's value for money. This is assumed to be reached when the same functions are provided at a lower cost and also when more value-adding functions are provided for the same or a lower cost. Improving a design's Value for Money performance requires the generation of creative ideas through the process of VE i.e. the 
organized approach for the provision of the necessary functions at the lowest cost (Kelly and Male 1993). VE's origins are traced back to the days of World War II, when due to material shortages, manufacturing engineers' focus was placed on the functions of a product. Their aim was to find ways to achieve the same functions without compromising quality. As Cheah and Ting (2005) note, the main emphasis of VE was not on cost reduction, but this came as a byproduct. Kalvakaalva and McDuff (2011) agree that VE is not only a cost-reduction methodology while retaining the functions and objectives; it also fosters thinking outside the box and moving beyond traditional methods to realize the maximum potential for expenditures.

According to Mao, Zhang and AbouRizk (2009), in the context of VE in construction, a multidisciplinary team reviews the project plan and assesses the possibility of improving the project value. The key stage of the process is a workshop session, where function analysis takes place and the brainstorming technique is usually applied to generate innovative ideas for enhanced project functions and reduced project costs. Short et al. (2007) provide a detailed analysis for the practice of VE and support that a progressive, client-driven use of VE, which relates back to a common sound understanding of the client's vision, offers some basis for success. Kalvakaalva and McDuff (2011) present the results of the VE exercise to the design of two multi-million highway projects in the US and conclude that it entailed cost savings ranging from $92 \mathrm{k}$ to $10 \mathrm{~m}$ for Project 1 and from 78k to 610k for Project 2. Examples of the VE's positive effect on functions like safety, traffic capacity, flood avoidance, reliability, durability, functionality, constructability, space utilization and long-term environmental impact have also been given by Yang, Baeg and Moon (2014) and Moon, Ha and Yang (2012) who report performance improvement up to $25 \%$ and $29 \%$ respectively, in road construction in Busan, 
Korea; Short et al. (2007) who report 20m savings in the redevelopment of the Haymarket Theatre in Leicester, UK; Mao, Zhang and AbouRizk (2009), who report up to 12\% performance improvement in the W12 Inverted Siphon Project in Edmonton, Canada.

Additional examples of projects with enhanced functional value, as specified in the above context, can also be drawn from the contemporary construction practice. For instance, the Stormwater Management and Road Tunnel (SMART) is a multi-purpose single-bore, two-level road tunnel constructed in Kuala Lumpur, Malaysia. The project was incepted primarily to mitigate the recurring floods in the city. However, at the design stage of SMART, the dual purpose concept was born from the ingenuity of the project proponents by integrating the motorway tunnel into the system to relieve traffic congestion at the main Southern Gateway to the city center. In light of this, the tunnel (diameter $13.2 \mathrm{~m}$ ) may alternatively operate (Figure 1a) as a road tunnel when weather is fair with little or no rain (Mode I), as a road tunnel and flood flow conveyor from the lower drains of tunnel when moderate rainfalls occur (Mode II) or as a passage of flood when prolonged heavy rain storms occur (Mode III). Another example of a project of great functional value is the A86 Duplex Tunnel, part of the $80 \mathrm{~km}$ A86 ring-road around Greater Paris (Paris Super-Peripherique), completed in January 2011 at a cost of $€ 2.2 \mathrm{bn}$. The project includes an innovative $10 \mathrm{~km}$ toll tunnel, with a diameter of $10.4 \mathrm{~m}$, for the exclusive use of light vehicles (with $2 \mathrm{~m}$-clearance height) and features two decks, each with two traffic lanes and one emergency lane. Each level is independent of the other, watertight and with individual air ventilation systems (Figure 1b). 
VE is normally conducted at the early design stage; the proper timing of VE implementation is of paramount importance to the final success of the process as post-design changes usually induce inefficiency and delays. For instance, Marinelli, Fragkakis and Lambropoulos (2015) report more than 30 major and minor design modifications in greek highway projects which could have significantly contributed towards value improvement and cost savings had they been identified and approved at the stage of design. However, VE should not be ruled out at the construction stage, as the contractor's practical experience and expertise, innovative construction plan and construction methods can also lead to substantial cost savings, better quality, and earlier project completion (Mao, Zhang and AbouRizk 2009). Indeed, the literature provides ample evidence that constructability i.e. the integration of construction knowledge and experience in design, can result in a wide range of value for money-enhancing benefits, including construction cost savings, reduced design rework and shortened project duration. Relevant examples have been given among others by: Gerth et al. (2013), who report 47\% performance improvement in a wall design used for two four-storey houses in Sweden; Bakti et al. (2011), who report cost and time savings of about 15\% in a seawater intake project in Indonesia; Jergeas and Van Der Put (2001), who refer to savings of $30-40 \%$ in the total installed costs of construction projects in Alberta; Pulaski and Horman (2005), who review the Wedge 1 Pentagon Renovation project and conclude that almost US\$ $3.5 \mathrm{~m}$ could have been saved had the constructability issues been identified at their appropriate time. The process of constructability review is complementary to VE and should be conducted in both the preliminary and developed design stages (Arditi, Elhassan and Toklu 2002). 
Additionally, flexibility is another characteristic that increasingly gets recognised as a value adding feature.Flexibility in the decision process marks an approach where decisions and commitments in the projects are made sequentially over episodes so as to adjust the project to prospective consequences of uncertain circumstances. It compares to owning an option - the right, but not the obligation to take an action in the future (Olsson 2006). In this context, De Neufville and Scholtes (2011) note that that areduced initial investment with the ability to expand easily in the future, not only lowers the risk of investment loss in case of bad performance, but also allows managers to take advantage of favourable opportunities whenever they appear. Both actions lead to greater expected value which, for major projects costing billions, can be worth hundreds of millions. Cardin (2014) confirms that flexibility has been shown in many case studies to improve the project's financial performance between $10 \%$ and $30 \%$ compared to the designs generated from standard design procedures.

The previous section has described the literature methods and tools to achieve best value for money in the design stage of construction projects, i.e. at a micro-level decision making. However, the foundations of an adequate cost efficiency perspective lie at the macro-level decision making, i.e. at the effective use of methodologies for demand forecasting, benefits appraising and costing at the earlier stage of planning. A study by the McKinsey Global Institute (2013) estimated that, of the US\$1trn in potential savings to be made in infrastructure globally, US\$200bn would come from improved asset selection and streamlining infrastructure portfolios through CBA and by looking more broadly at project objectives. 
CBA is a widely used ex-ante evaluation approach, mainly, for reviewing the feasibility of infrastructure projects' development. By means of a CBA, the welfare contribution of a project to a region or a country can be measured and, in so doing, the contribution of the investment to growth objectives can be assessed. For instance, in the context of road transport projects, CBA would be used to evaluate how the alternative options of building a new connection or adding capacity and quality to the existing road network compare over serving the national or regional economic development goals and interregional transport needs. The welfare indicators for evaluation of the options would include shorter transit times, increased road safety, reduced congestion and less pollution, while the expected impact on economic development could be related to the number of new jobs in the region, number of jobs due to the construction activity and maintenance and the potential tourism activity. The European Commission's (EC) CBA Guidelines (2014) highlight the importance of a prior in-depth analysis of the socio-economic context of the investment in achieving credible forecasts of the associated benefits and costs.

Furthermore, the demand forecast is a key factor for the efficient design of the project and the proper estimation of its returns and financial performance in the context of CBA. For instance, the design of the roads and the definition of their technical specifications are based on estimates of future traffic which if inaccurate may lead to the selection of a road type not best suited to the traffic needs. The ECA (2013) following a value for money audit of 19 road projects in Germany, Greece, Poland and Spain concluded that only four out of 19 projects carried volumes of traffic which were in line with forecasts. This means that thet raffic needs could have been accommodated by express roads which are by $43 \%$ cheaper compared to the actually implemented option of motorways. Vassallo, Baeza and Ortega (2012) observe that the lack of 
complete CBAs for Spanish toll highways was among the reasons for the inefficient course of the relevant investments. Along the same lines Flyvbjerg (2008) argues that CBA for large infrastructure investments typically combine cost and demand forecasts which involves the risk of inaccuracy to the second degree. Similarly, Fabbro, Brunello and Dean (2015), referring to the Italian motorways, highlight the risk for the decision makers to be blinded by the temptation to exaggerate opportunities and potentialities, while ignoring the strategic importance of contextual constraints and the role of existing infrastructures. Along the same lines, Marinelli, Fragkakis and Lambropoulos (2015) make reference to major transport infrastructure projects in Greece (railway, ports, airports) which remain extremely underused and thus represent highly inefficient investment decisions. Similar cases concerning almost every EU Member State across all the categories of infrastructure projects have been highlighted in various reports of the ECA(2013, 2014a, 2014b).

The ultimate goal of the analysis conducted in the context of CBA lies in assuring that the funds are invested in economically viable projects, i.e. projects able to deliver sufficient returns on investments. The indicators used to assess project viability include economic net present value (ENPV) and the benefit-cost (B/C) ratio, which both actually express the balance between the value of the increased welfare and development performance expressed in money terms and the construction cost of the technical solution chosen. In this context, there is an apparent interconnection between the indicators used to facilitate macro-level decision making and the cost and value features of the design alternatives scrutinized by means of the micro-level VE activities. For instance, ECA (2013) refers to the case of E75/PATHE Motorway in Greece, which was selected by the EU for funding on the premise that its cost was equal to $€ 278$ million 
and its associated $\mathrm{B} / \mathrm{C}$ ratio equal to 3.1. However, the actual construction cost of the project was elevated to $€ 378$ million, which means that the equivalent $\mathrm{B} / \mathrm{C}$ ratio, all other factors being unchanged, decreased to 2.3 .

\section{RETHINKING PUBLIC INVESTMENT VALUE FOR MONEY IN GREECE}

Greece is an example of a country long using its public resources less than optimally (Monastiriotis and Psycharis 2014). Dimitriou, Mourmouris and Sartzetaki (2015) note that large-scale projects can provide substantial economic opportunities to change the current economy trends, provided that government agencies, authorities and stakeholders are prepared to achieve the benefits in an efficient and effective manner. Therefore under the current circumstances where the limited resources for public investment deplete and the country is more and more dependent on external loans, the return to growth urgently mandates an infrastructure development plan with projects achieving the highest possible level of cost-efficiency. This section gives examples of projects currently under consideration/design in Greece along with the authors' recommendations and proposals for substantial improvement of their value for money performance.

\section{Thessaloniki ring road}

Thessaloniki is the second largest Greek city, with a population of approximately 1 million. As a result of the area's morphology along a semi-crescent and the current land-use planning (industrial zones in the west side, airport and residential area in the east side), the capacity of its ring road has well been exceeded. To accommodate the existing needs, the upgrading of the ring was decided with a new 8-km motorway section, parallel to the existing one; a pre-design 
comprising a series of twin tunnels at most of its length was conducted and approved by the Client, a Public Entity. However, an alternative "fly over" design solution, as shown in Figure 2a, was later adopted by the Client, following proposal by the authors inspired by the Southern Crosstown Expressway (Figure 2b) constructed in 2007 in Tampa, Florida (length 8 km, cost US\$ 400 million). This alternative 'value-engineered' design resulted not only in the construction cost being at the $60 \%$ of the tunnel's cost but also in much lower operation and maintenance costs and a significantly reduced environmental impact. Furthermore, the construction would be based on prefabricated elements, which is highly desirable from a constructability point of view, as it only entails a very limited traffic interruption. Apparently, the alternative design represented a much higher value for money as a result of both the valueadding improved environmental and constructability performance and the lower cost. The final design of the fly-over is currently in progress. This example confirms the view that ability supported by competence and commitment to explore construction method options in a flexible manner are necessary to facilitate good construction performance (Walker and Shen 2002).

\section{Thessaloniki pedestrian pathway on sea}

The center of Thessaloniki faces heavy traffic congestion problems. A concession contract, comprising a $1.3 \mathrm{~km}$ submerged tunnel by-passing the city center along its seafront, was tendered and awarded by the Greek Ministry of Infrastructure at a cost of approximately $€ 700$ million. The tunnel would enable the better use of adjacent roads and, thus, the creation of a $4.5 \mathrm{~km}$ avenue connecting the east and west sections of Thessaloniki. Unfortunately, after the contract had been awarded, the Ministry of Culture / Archaeological Service imposed the construction of a bored tunnel instead, in order to protect possible remnants of a naval battle of the 7th century 
AD. This raised the cost to approximately $€ 900$ million and after the Concessionaire's objections the contract was terminated. As a result, the Arbitration Court decided that the Greek State is obliged to pay a penalty of more than $€ 100$ million.

Currently, the Municipality of Thessaloniki examines an alternative option of improved constructability and much lower cost: the use of the existing $6.5 \mathrm{~m}$ wide seaside pedestrian pathway by vehicles and the construction of a parallel $10 \mathrm{~m}$ wide and $1 \mathrm{~km}$ long wooden light platform on piles to accommodate pedestrian and bicycle uses (Figure 3). This option was proposed by the authors with the support of a design office; it was inspired by the construction, first, of a $140 \mathrm{~m}$ long and $8 \mathrm{~m}$ wide similar wooden pathway on piles along a dock by the Thessaloniki Port Authority for recreational use and, second, of a similar $4 \mathrm{~m}$ wide wooden pathway in the small 'historical' port of Rhodes. This value-engineered solution allows the bidirectional movement of vehicles (with two lanes per direction) on the existing littoral road and largely achieves the traffic relief benefits expected by the under-sea bypass. Furthermore, it greatly improves the pedestrians' experience and all these at the $3 \%$ of the initial solution's cost. Though the traffic along the seafront will increase with the associated negative environmental impacts, these will be over-counterbalanced by the overall traffic and congestion decrease in the wider area of the city. Therefore, the proposed alternative obviously constitutes a design option of much higher value for money.

\section{Hymettus Peripheral Road in Athens}

The Greek capital, Athens, with a population of over 4 million, is situated between the seafront and a semi-circular series of mountains. Due to its location, the peripheral roads across the mountains are of vital importance. In 2009, the designs for a $14 \mathrm{~km}$ extension to the south-east of 
the agglomeration, along Hymettus mountain, were completed. A concession contract, including a series of twin tunnels covering almost all the above length, was prepared for tendering with an estimated budget of approximately $€ 900$ million. However, after a governmental change, an alternative technical solution was examined and finally included in the updated Athens Master Planratified by law in 2014. This consists of, first, a new twin $3.5 \mathrm{~km}$ tunnel connecting the existing peripheral road on the mountainside to an existing avenue on the plain level, and, second, the upgrading of the avenue at a length of $10 \mathrm{~km}$ to a free flow expressway. ECA (2013) notes that the construction of one $\mathrm{km}$ of a new road project is twice as expensive compared to the upgrading of an existing road. Indeed, the cost was estimated to be half of the cost of the initial design solution, i.e. $€ 200$ million for the tunnel and $€ 250$ million for the upgrading. However, the stringent financial circumstances require seeking for even more cost-efficient design options. Following an authors' proposal inspired from the Paris super-peripherique Duplex Tunnel and similar technical solutions worldwide, and with the support of three design offices, the awarding authority currently reviews an alternative design option for the tunnel part of the project. This involves a 3.5-km two-level, single bore, double-deck tunnel for light vehicles at an estimated cost of $€ 120$ million, i.e. at a cost $40 \%$ lower.

\section{Urban Development Projects in Greater Athens}

The Greek Ministry of Infrastructure submitted two years agoto the EC for co-financing two major urban projects. The EC refused their approval, claiming that they were decorative in nature and Greece's priority should be the completion of the Trans European Transport Network (TENT). The first project concerns the revitalization of the wider historical center of Athens and its market. It foresees the center's pedestrianization, the banning of private cars and the construction 
of tramways, gardens, fountains etc. at a cost of $€ 110$ million. The project has been criticized by many experts for various reasons including the lack of an integrated city master plan to belong to, incomplete traffic studies and lack of consultation with the local stakeholders on the policies required for the successful regeneration of the market area.

However, as Priemus (2010) and De Jong, Annema and Van Wee (2013) note, the world changes while the project is being constructed; important changes relate to traffic demand, governments, policies and regulations, human and financial resources and technical developments. Therefore, in the previously presented context of project flexibility and taking into account the widely discussed contribution of modularity to value generation under uncertainty (e.g. Olsson 2006, Cardin 2014, De Neufville and Scholtes 2011), one possible way of dealing with such changes is by dividing the project into two distinct stages. The first stage would include interventions which require a small part of the total budget and can be easily reversed, e.g. the pedestrianisation, the traffic arrangements (placement of barriers on the streets, rearrangements of traffic lights, new traffic signs, preservation of existing bus lanes, painting of lanes etc.) and the development of the necessary exploitation policies. The second stage would include the expensive construction of tramways, gardens, fountains etc., and would be implemented if and when the first stage proves to be successful. Until today no further action is taken by the State on this project.

The second project foresees the upgrading of a 3-km sea-front strip at Faliro Bay in Athens (Figure 4, area a). It includes the construction of an Underground Avenue, anti-flooding technical works, low buildings, marinas, gardens etc. at a cost of $€ 320$ million. Following the same reasoning of modular execution, the proper way to implement the project would be to split 
it in two distinct stages. First, the construction of the absolutely necessary works which would enable the citizens to enjoy the sea-front at a small part of the total budget (anti-flooding technical works, small earthworks, pedestrian and cyclist paths along the shore etc) and at a later stage the construction of the remaining costly works, when the economy will recover and more financing resources will be available.

The aforementioned flexible approach would enable the State to decide whether and when it makes sense to invest more and is highly suitable for projects that for political or other reasons are pushed to a premature go-ahead decision (Olssen 2006), which is very relevant to the Greek reality and practice. Nevertheless, the Region of Attica decided to finance the project solely from its own limited resources, i.e. without European co-financing, and a construction contract was awarded recently.

\section{New Cruise Port in Piraeus}

Tourism by cruise ships is developing quickly in the Mediterranean Sea. This is particularly evident in the case of Piraeus where the increasing demand creates the need for a new cruise port. The initial plan of the Port Authority in 2012 foresaw the construction of six new piers in the mouth of the main port (Figure 4, area b), to be founded at the seabed, in depth of 60 meters. However, this location involves an elevated construction cost estimated at $€ 80$ million per pier, due to the high depth, as well as an increased safety risk, resulting from high ship traffic generated by the large nearby container port. The authors, with the support of a design office, proposed to the responsible Ministry of Infrastructure an alternative option of much improved constructability, value and cost-efficiency; this foresees the construction of an equivalent cruise port at the nearby Faliro Bay (Figure 4, area c), where the foundation depth is 14 meters and the associated cost is approximately $60 \%$ of the cost of the initial solution. Furthermore, from that 
location there is easy access to existing metro, tramway and express road leading to the Acropolis and museums. In the years that followed, the port of Piraeus was privatized and no further action was taken to present.

\section{Mobility Policy}

In 2004, a new 40km long urban railway line in the central reserve of the Athens Ring Road ("Attiki Odos") started its operation. However, apart from meeting user needs, the most important aspect to consider when assessing the performance of public transport is the level of usage and possibly the modal shift, e.g. people who change their mode of transport from private car to mass transport mode. The above can be severely affected by an inadequate mobility policy, i.e. the lack of coordination between modes of transport and with parking policy (ECA 2014a). In this context, the aforementioned urban railway line cannot possibly meet its full potential, since there are no transit bus facilities to its stations, nor adequate park and ride facilities to properly serve the users. Although suitable areas owned by the State exist close to the stations (i.e. the ex-construction sites of the Ring Road) and could obviously be used as bus stations or for park and ride, these are to be sold by the State for other commercial uses. Thus, it is beyond any doubt that a more efficient management of land uses is required to enable the creation of synergies and interconnections between transport modes. The value-adding capabilities of such synergies are particularly highlighted by the international experience. For instance, Vassallo, di Ciommo and Garcia (2012) report that the intermodal exchange stations helped commuters to save travel time, bus companies to diminish their costs of operation, private operators to make a fair profit and the government to promote these infrastructure facilities without spending more of its scarce budgetary resources. Furthermore, the ECA (2014a) 
provides examples from a light metro line in Portugal where the actual utilization has plummeted to $-87 \%$ compared to the forecasts as a result of the poor quality of the transportation services offered by the bus network and of the lack of park and ride facilities at both ends of the line, while parking spaces are available at attractive prices in the city centre. ECA also refers to a new tram line in Italy which, on the contrary, reached an impressive $113 \%$ of the target demand as a result of good coordination with the bus network and integration of fares. Therefore, in the case of the above railway line it is imperative that intermodal exchange facilities are constructed to enable the modal transfer of commuters.

\section{New International Airport in Crete}

The island of Crete, one of the biggest in the Mediterannean Sea, requires a new airport to serve the needs of both its population (about 600,000 ) and the millions of tourists visiting the island every year, mainly by air. The existing international airport is the 2nd busiest in Greece, after Athens International Airport, with almost 7million passengers annually using over 50 airlines. Despite its landside infrastructure (terminal) extension in the last decade, the airport remains over-saturated due to its very high 5-month seasonal use. Indicatively, ECA observed in its audit report (2014b) a 40\% higher additional passenger numbers for 2013, compared to the forecasts. Furthermore, as the airport is built within the boundaries of the capital city of Crete, Heraklion, at the sea-side, neither the expansion of its airside infrastructure (runway, taxi-way etc) is a feasible option.

In response to this demonstrated need for expansion, the construction of a new international airporthas been plannedat a distance of $30 \mathrm{~km}$ ("Minoa plain") with designs foreseeing a runway 
of $3,800 \mathrm{~m}$ with its taxiway, buildings, access roads etc. at an estimated cost of $€ 800$ million. The project was tendered in 2012 as a concession, with a State financial contribution of €200 million(plus $€ 80$ million for expropriation cost).Garvin and Cheah (2004) and De Jong, Annema and Van Wee (2013) note that private capital sources assist the authorities to meet the society's needs amidst funding constraints and can improve the value for money performance of projects. Therefore, under the current financial circumstances, the option of PPPs is highly appropriate. However, due to the Greek financial crisis, no offers were received for this project, although specialised consortia had initially expressed their interest.

Recently, the project was tendered again; the only substantial change in its technical characteristics is the reduction of the runway length to $3,200 \mathrm{~m}$ with the option to increase it to 3,800 later, if necessary. Almost the very same specialized consortia scrutinize the project but since the interest rates remain very high, there was only one offer at $€ 660$ million (including the requested State Financial Contribution). This offer is under evaluation at the moment; although the process is legitimate, the apparent lack of competition is at all events a sign of poor value for money. This situation could have been avoided had the authorities followed the European PPP Expertise Center's guidance (EPEC 2009, 2010), which foresees that under adverse financial circumstances, loans and lenders can be jointly selected with the Concessionaire, at a later stage.

In this context, in order to overcome the current situation without significant time loss, the State should have incorporated flexibility in the decision making as described in the previous section, i.e. combine the efficient utilization of existing infrastructure after small-scale improvement with the rational planning of new investment. Such an approach is also in line with IATA's and the 
EC's recommendation for the expansion of airport infrastructure in phases and at intervals as it enables the authorities to make better use of the existing capacity in the first instance and only build infrastructure which are proven to be necessary and have a satisfactory medium-term prospects for use (ECA 2014b). Specifically, the State should have taken action towards a low cost (€5 - €10 million) upgrading of the existing airport's landside infrastructure capacity with inflated or light construction parts (membrane trusses) in tandem with the utilization of the closest airport, i.e. the military airport at Tymbaki, during the summer period (AprilSeptember). The latter would also require a low-cost upgrading ( $€ 5-€ 10$ million) of the runway (pavement improvement) as well as a similar expansion of its building premises. The ECA (2014b) gives examples of similar upgrading and expansion arrangements in various EU Member States and highlights the role of investments in neighbouring airports towards the optimal use of EU funds.

In parallel, a Master Plan should have been rapidly prepared for the existing airport wider area foreseeing a mild urban development of the littoral area which, according to initial estimations by the relevant Public Service, can bring to the State revenues that suffice to cover the total cost of the new Airport.

\section{DISCUSSION}

The examples of Thessaloniki ring road (fly-over), Thessaloniki pedestrian pathway on sea, Hymettus Peripheral Road (double deck tunnel), and Piraeus New Cruise Port aptly demonstrate how the principles of VE and Constructability were used to achieve higher value for money. In 
particular the proposed fly-over and double deck tunnel engineering solutions make obvious the benefits resulting from incorporating the international construction practice and experience. Moreover, the cases of the two urban development projects in Athens and the International Airport in Crete are mainly linked to the additional value that could be generated by the suggested design flexibility. Finally, the mobility policy case (intermodal exchange facilities construction) illustrates the missed value resulting from the poor interconnection between the traffic demand forecasts, planning and CBA, as well as the indifference of the responsible Authorities to take corrective action. These examples highlight the urgency for the Greek Ministry of Infrastructure to improve, in short time, its project planning processes. Besides, the fact that the EC keeps rejecting a considerable number of proposals for co-financing of projects in Greece after 20 years of Community Support Programmes, points to the very same direction.

Although the above have been drawn to the attention of the responsible Authorities, along with the detailed presentation of the technical solutions, the decisions made for most of the projects demonstrate that the appreciation of cost efficiency as an urgent need for current investments in Greece is still far from the required level, despite the stringent budgetary constraints. Therefore, a critical question arises: what are the barriers that prohibit the adoption and implementation of well documented and worldwide applied analytical methods, procedures and construction techniques by the Greek public clients, even in such adverse economic circumstances, in order to achieve value for money in infrastructure investments?

First of all, the answer lies in the fact that the policy and decision makers, irrespective of their party and background, tend to promote large and impressive new projects to associate their name 
with and benefit in terms of votes. Besides, the staged development of a large investment (e.g. the new airport in Crete) extends beyond their term in office; therefore it is not attractive as a planning approach, even though it increases substantially the chance of success. Similarly, the construction of the new cruise port within the boundaries of a larger city and not a smaller town (i.e. in Piraeus and not in Faliro), is preferable for politicians, despite being more costly, as it will influence positively more voters. Along the same lines, a rather small investment aiming at improving the functionality of an existing infrastructure (e.g. construction of intermodal exchange facilities in existing urban railway stations) can hardly be exploited politically; therefore it is not attractive, even if it presents the highest value for money.

Additionally, the Public Administration staff lack the necessary knowledge and expertise required to manage investments in infrastructure efficiently and effectively. This is mainly due to the non-objective selection procedures applied for the managerial posts, coupled with the lack of interest by the Administration's side to pursue opportunities for systematic collaboration with academia and obtainment of international knowledge for dissemination to their staff. Consequently, as happened in the projects previously presented, costly technical solutions are being adopted over alternatives with much higher value for money (e.g. technical solutions of fly-over, wooden deck on piers, double deck tunnel).

Furthermore, the design offices also tend to promote large public infrastructure projects given that their remuneration is proportionally linked to the project budget and have no financial interest in applying value for money techniques, while professional associations, political parties etc, are showing no real interest in safeguarding value from tax-payers' money in public works. 
Last but not least, there are no legal provisions for a systematic impartial ex-post evaluation of construction projects in terms of actual traffic, technical solutions, investment cost, functionality etc. As a result, the audits conducted by the Public Administration Inspecting bodies as well as the Greek Court of Auditors, instead of dealing with the substantial technical and financial features of the projects, look into secondary legal and accounting issues.

The lessons learnt from the analysis of the previous section include the fact that major projects such as transport projects should have clear objectives linked to appropriate indicators and CBA. CBA should be obligatory by law and conducted by experienced consultants with great thoroughness and cautiousness as regards the reliability and sufficiency of the traffic data used to underpin the analysis. The demand forecasts should be subject to rigorous testing of sensitivity to alternative assumptions for the mobility needs, in light of the fact that transport is a derived demand and has a strong link with the economic situation. Therefore, especially for the case of Greece, the impact of the international economic crisis and the continuous recession should be taken into account when analyses are carried out at the design and planning phase.

Furthermore, the selection of reasonable and cost-effective technical solutions should be an integral part of the feasibility study. Therefore, option analysis focusing on cost minimization and value maximization should be carried out before project tendering by the Public Clients, for the best solution determination. 
Moreover, the flexible implementation of projects in stages and synergies with other projects should be used to enhance their viability prospects. This is due to the fact that when projects belong to networks, their demand, and consequently their financial and economic performance, is highly influenced by issues of mutual dependency and accessibility. For instance metro/tram/rail projects can greatly benefit from better alignment or expansion of the bus services and creation of parking places to the terminal stations.

Additionally, in order for the necessary project appraisals to be conducted, a different organizational structure is necessary: a special purpose Office staffed by checkers and reviewers specializing in project management, CBA and technical/ engineering issues should be created with the relevant reviews being applicable to all the projects to be tendered. This would in turn require commensurate investment in structuring impartial and effective procedures and in developing people's skills, i.e. the Public clients should train their personnel appropriately and possibly hire external experts for additional support.

\section{CONCLUSIONS}

The global financial crisis and the fiscal crisis that followed inside the Eurozone have put significant strain on public finances in most countries in Europe. Especially in Greece, the recession has had a profound adverse impact on projects' planning and has been a significant challenge for the prioritization of public investment. As government budgets and credit remain tight, the role of private capital has expanded further and attention is turning to capital efficiency.

The international practice reveals that the main drivers for cost-efficient infrastructure investments are the preparation of thorough feasibility studies, the accurate demand forecasts 
through well-informed CBAs and the timely design decisions made in the light of maximum value achievement, flexibility and constructability. Nevertheless, in the context of Greece, the presented transportation projects and the associated designs demonstrate that there is still much room for improvement as there are alternative design options which entail lower cost and / or higher value and thus achieve a significantly greater value for money. This research highlights the critical role of VM, VE and CBA in decisions with key impact on the investments' cost and provides valuable insight in the practical dimension of these practices. Therefore it is very relevant to all public clients striving for capital efficiency in recession times as well as to academic researchers in the field of infrastructure planning policies and investment appraisal.

\section{REFERENCES}

Arditi, D., A. Elhassan and Y.C. Toklu. 2002. Constructability analysis in the design firm, ASCE Journal of Construction Engineering and Management 28, no. 2: 117-26.

Bakti, E.S., M.Z.bin Abdul Majid, R.M. Zin and B. Trigunarsyah. 2011. Constructability improvement in seawater intake structure", Engineering, Construction and Architectural Management 18, no.6: $595-608$.

Bertolini, L., A. Wenban-Smith, M. Robiglio, B. Williams, E. van der Kooij and L. Bertolini. 2011.Planning and the Recession. Planning Theory and Practice12, no. 3: 429-51.

Cardin, M.A. 2014. Enabling Flexibility in Engineering Systems: A Taxonomy of Procedures and a Design Framework, Journal of Mechanical Design 136, no. 1:011005-1-14.

Cheah, C.Y.J., and S.K. Ting. 2005. Appraisal of value engineering in construction in Southeast Asia, International Journal of Project Management 23, no. 2:151-58.

De Jong, M., J.A. Annema and G.P. Van Wee. 2013. How to Build Major Transport Infrastructure Projects within Budget, in Time and with the Expected Output; a Literature Review". Transport Reviews 33, no. 2: 195-218.

De Neufville, R. and S. Scholtes. 2011. Flexibility in Engineering Design. MIT Press.

Dimitriou, D., J. Mourmouris and M. Sartzetaki. 2015. Economic impact assessment of mega infrastructure pipeline projects, Applied Economics 47, no 40: 4310-22.

Ellis, R.C.T., G.D. Wood and D.A. Keel. 2005. Value management practices of leading UK cost consultants. Construction Management and Economics 23, no. 5: 483-93. 
European Commission, Directorate General Regional Policy.2014. Guide to Cost-Benefit Analysis of Investment projects -Economic appraisal tool for Cohesion Policy 20142020. Report available at http://ec.europa.eu/regional_policy/sources/docgener/studies/pdf/cba_guide.pdf

European Court of Auditors 2013. Are EU Cohesion Policy Funds well spent on Roads? Special Report No 5, available at http://www.eca.europa.eu/Lists/ECADocuments/SR13_05/SR13_05_EN.PDF

European Court of Auditors. 2014a. Effectiveness of EU-supported public urban transport projects, Special Report No 1, available at http://www.eca.europa.eu/Lists/ECADocuments/SR14_01/QJAB14001ENC.pdf

European Court of Auditors. 2014b. EU-funded airport infrastructures: poor value for money, Special Report No 21, available at http://www.eca.europa.eu/Lists/ECADocuments/SR14_21/QJAB14021ENC.pdf

European PPP Expertise Center. 2009. The financial crisis and the PPP market. Report available at http://www.eib.org/epec/resources/epec-credit-crisis-paper-abridged.pdf

European PPP Expertise Center. 2010. Capital markets in PPP financing. Where we were and where are we going? Report available at http://www.eib.org/epec/resources/epec-capitalmarkets.pdf

Fabbro, S., L. Brunello and M. Dean. 2015. Reframing Large Transport Infrastructure Plans: A Study on European Corridors with a Focus on North-eastern Italy, International Planning Studies 20, no. 4: 323-49.

Flyvbjerg, B. 2008. Curbing Optimism Bias and Strategic Misrepresentation in Planning: Reference Class Forecasting in Practice. European Planning Studies 16, no. 1: 3-21.

Garvin, M.J., and C.Y.J. Cheah. 2004. Valuation techniques for infrastructure investment decisions. Construction Management and Economics 22, no. 4: 373-83.

Gerth, R., A. Boqvist, M. Bjelkemyr and B. Lindberg. 2013. Design for construction: utilizing production experiences in development. Construction Management and Economics 31 no. 2: $135-50$.

Jay, C.J. and P.A. Bowen. 2015. Value Management and Innovation; A historical perspective and review of the evidence, Journal of Engineering ,Design and Technology 13, no.1: 123-143.

Jergeas, G., and J. Van der Put. 2001. Benefits of Constructability on Construction Projects. ASCE Journal of Construction Engineering and Management, 127, no. 4: 281-90.

Kelly, J., and S. Male. 1993. Value Management in Design and Construction: The Economic Management of Projects, E \& FN, Spon, London.

Kelly, J., S. Male and D. Graham. 2004. Value Management of Construction Projects, Blackwell. 
Kalvakaalva, R., and C. McDuff. 2011. Value Engineering Methodology during an Economic Recession "Thinking Outside the Box". AASHTO Value Engineering Peer Exchange Workshop, New Orleans, Louisiana.

Lovering, J. 2010. Will the Recession Prove to be a Turning Point in Planning and Urban Development Thinking? International Planning Studies 15, no. 3: 227-43.

Mao, X., X. Zhang and S.M. AbouRizk. 2009. Enhancing value engineering process by incorporating inventive problem-solving techniques, ASCE Journal of Construction Engineering and Management135, no. 5: 416-24.

Marinelli, M., N. Fragkakis and S. Lambropoulos. 2015.The Development of the TransEuropean Transport Network in Greece: A Review and Critique. In proceedings of the 8th International Conference on Construction in the 21st Century (CITC-8), ed. S.M. Ahmed, Xenidis, Y., Azhar, S., Smith., N.A., Yaris, S.E. and Campbell, S., 23-30. Greenville, N Carolina, USA.

Matsaganis, M., and C. Leventi. 2014. The distributional impact of austerity and the recession in Southern Europe. South European Society and Politics19, no. 3: 393-412.

McKinsey Global Institute. 2013. Infrastructure productivity: How to save \$1 trillion a year http://www.mckinsey.com/industries/infrastructure/our-insights/infrastructure-productivity

Monastiriotis, V. 2011. Making geographical sense of the Greek austerity measures: compositional effects and long-run implications. Cambridge Journal of Regions, Economy and Society 4, no. 3: 323-37.

Monastiriotis, V., and Y. Psycharis. 2014.Between equity, efficiency and redistribution: An analysis of revealed allocation criteria of regional public investment in Greece. European Urban and Regional Studies 21, no.4: 445- 62.

Moon, S., H. Chideok and J. Yang. 2012. Structured idea creation for improving the value of construction design, ASCE Journal of Construction Engineering and Management 138, no. 7: 841-53.

National Audit Office. 2013. Planning for Economic Infrastructure, Report by the Comptroller and Auditor General.https://www.nao.org.uk/wp-content/uploads/2013/03/Economicinfrastructure-full-report.pdf

Olsson, N.O.E. 2006. Management of flexibility in projects, International Journal of Project Management 24, no.1: 66-74.

Priemus, H. 2010. Decision-making on mega-projects: Drifting on political discontinuity and marketDynamics.European Journal of Transport and Infrastructure Research 10, no. 1: $19-29$.

Pulaski, M., and M. Horman. 2005. Organizing constructability knowledge for design. ASCE Journal of Construction Engineering and Management 131, no. 8: 911-19.

Reeves, E. 2015. A Review of the PPP Experience in Ireland: Lessons for comparative policy analysis. Journal of Comparative Policy Analysis 17, no. 5:467-80.

Salvatierra-Garrido, J. and C. Pascuire. 2011. Value theory in lean construction, Journal of Financial Management of Property and Construction 16, no.1: 8-18. 
Short, C.A., P. Barrett, A. Dye and M. Sutrisna. 2007. Impacts of value engineering on five Capital Arts projects. Building Research \& Information 35, no. 3: 287-315.

The Economist Intelligence Unit. 2014. Future-Proofing Infrastructure Assets Building capitalefficient infrastructure in the age of austerityhttp://www.economistinsights.com/infrastructure-cities/analysis/future-proofinginfrastructure-assets

Vassallo, J.M., M.A. Baeza and A. Ortega. 2012. What was wrong with the toll highway concessions in the Madrid Metropolitan area? Canadian Journal of Civil Engineering 39: $81-90$.

Vassallo, J.M., F. Di Ciommo and A. Garcia. 2012. Intermodal exchange stations in the city of Madrid. Transportation 39:975-95.

Walker, D.H.T., and Y.J. Shen. 2002. Project Understanding, Planning, Flexibility of Management Action and Construction Time Performance: Two Australian Case Studies. Construction Management and Economics 20, no. 1:31-44.

Yang, J., H. Baeg and S. Moon. 2014. Utilization of contradiction for creating value design alternatives in construction value engineering, KSCE Journal of Civil Engineering 18, no.2: 355-64. 